\title{
Reflections of academic and professional leaders on leadership in a higher education institution
}

\begin{tabular}{|c|c|}
\hline \multicolumn{2}{|c|}{$\begin{array}{l}\text { Authors: } \\
\text { Jose Frantz }{ }^{1} \\
\text { Vivienne Lawack } \\
\text { Anthea Rhoda }^{1}\end{array}$} \\
\hline \multicolumn{2}{|c|}{$\begin{array}{l}\text { Affiliations: } \\
{ }^{1} \text { Department of } \\
\text { Physiotherapy, Faculty of } \\
\text { Community and Health } \\
\text { Sciences, University of the } \\
\text { Western Cape, Cape Town, } \\
\text { South Africa }\end{array}$} \\
\hline \multicolumn{2}{|c|}{$\begin{array}{l}{ }^{2} \text { Department of Mercantile } \\
\text { and Labour Law, Faculty of } \\
\text { Law, University of the } \\
\text { Western Cape, Cape Town, } \\
\text { South Africa }\end{array}$} \\
\hline \multicolumn{2}{|c|}{$\begin{array}{l}\text { Project research number: } \\
130416-049\end{array}$} \\
\hline \multicolumn{2}{|c|}{$\begin{array}{l}\text { Corresponding author: } \\
\text { Jose Frantz, } \\
\text { jfrantz@uwc.ac.za }\end{array}$} \\
\hline \multicolumn{2}{|c|}{$\begin{array}{l}\text { Dates: } \\
\text { Received: } 11 \text { Apr. } 2020 \\
\text { Accepted: } 16 \text { Sept. } 2020 \\
\text { Published: } 20 \text { Nov. } 2020\end{array}$} \\
\hline \multicolumn{2}{|c|}{$\begin{array}{l}\text { How to cite this article: } \\
\text { Frantz, J., Lawack, V., \& } \\
\text { Rhoda, A., (2020). } \\
\text { Reflections of academic and } \\
\text { professional leaders on } \\
\text { leadership in a higher } \\
\text { education institution. SA } \\
\text { Journal of Human Resource } \\
\text { Management/SA Tydskrif vir } \\
\text { Menslikehulpbronbestuur, } \\
\text { 18(0), a1373. https://doi. } \\
\text { org/10.4102/sajhrm. } \\
\text { v18i0.1373 }\end{array}$} \\
\hline \multicolumn{2}{|c|}{$\begin{array}{l}\text { Copyright: } \\
\text { (c) 2020. The Authors } \\
\text { Licensee: AOSIS. This } \\
\text { is licensed under the } \\
\text { Creative Commons } \\
\text { Attribution License. }\end{array}$} \\
\hline \multicolumn{2}{|l|}{ Read online: } \\
\hline ary & $\begin{array}{l}\text { Scan this QR } \\
\text { code with your } \\
\text { smart phone or } \\
\text { mobile device } \\
\text { to read online. }\end{array}$ \\
\hline
\end{tabular}

Orientation: Higher education institutions are under pressure to address the challenge of the leadership pipeline. Therefore, the need exists to explore the potential of current leaders and their views of leadership in higher education.

Research purpose: The study aimed to explore the views of how academic and professional support leaders have shifted their thinking of and approach to leadership following their participation in a leadership development programme.

Motivation for the study: Understanding the views of potential leaders about leadership and how leadership development programmes can influence their thinking is essential.

Research approach/design and method: Qualitative data was gathered by means of a document analysis using reflections submitted by 19 participants of a leadership development programme.

Main Findings: The results showed that the programme had an impact on how participants started reflecting on leadership styles beyond the usual description of leadership styles. Additionally, participants used the opportunity for introspection of their own role as a leader and how they need to adapt.

Practical/managerial implications: Higher education institutions are encouraged to implement leadership development programmes that will encourage stakeholders to engage in introspective activities that could influence behavioural change.

Contribution/value-add: It is evident from the results that the information is useful in indicating how participants had made personal adjustments in the way they viewed leadership with a greater sense of ownership and understanding of distributed leadership through the participation in a leadership development programme.

Keywords: academic; higher education; leadership development; reflections; professional support leaders.

\section{Introduction}

\section{Orientation}

Universities in South Africa are in a period of change. In addition, there is increasing evidence that South Africa is facing significant higher education leadership succession challenges (Seale, 2015). One of the succession challenges in South African universities is the trend of appointing academic staff in leadership positions who have limited or no formal leadership training (Parrish, 2015). More than a decade ago, Kulati (2001) highlighted that studies on leadership in South African higher education institutions (HEI) were not receiving enough attention. Fourteen years later, Seale (2015) concluded in his study that there remains inadequate preparation of academic leaders, especially at the level of Deans, and emphasised the need for an integrated approach to leadership development. The author also concludes that the higher education sector needs leaders who focus on the needs of the collective rather than the individual. In addition, Jones, Harvey, Lefoe and Ryland (2014) highlighted that there is a need for a different form of leadership, such as a leadership style that recognises the complexity of formal and informal leadership in higher education. In addition, there is a need to acknowledge the past, whilst engaging with an uncertain future where accountability becomes more formalised and stakeholders' demands increase. Therefore, it is important to explore the current potential of leaders as well as their view of leadership in higher education to address the challenge of the leadership pipeline. 


\section{Research purpose and objectives}

Effective leadership largely enables HEIs to meet current demands and contributes to institutional reform and transformation. However, effective leadership is characterised by general and specific competencies aligned to the needs of an institution. Therefore, effective leadership within higher educational institutions may vary from traditional leadership leading to the rethinking of effective leadership within this sector. It becomes essential for leaders to understand their leadership style and how it may influence others in order to reach a shared desired goal. Leadership development programmes may provide a platform for the rethinking of effective leadership in HEI and provide individuals in leadership roles the opportunity to reflect upon their leadership styles and its impact on others. Therefore, the purpose of this article is to explore the views of how academic and professional support leaders have shifted their thinking of and approach to leadership following their participation in a leadership development programme. Academic staff is a staff in a leadership position, such as Head of Department (HOD), Deputy Deans and Deans, and professional support staff includes faculty managers and deputy registrars.

\section{Literature review}

The growing interest in the role of leaders within HEIs in recent years was driven both by the influence of HEIs in developing learners who later develop as leaders in wider society and by the changing shape of higher education leadership itself in the face of global challenges in the sector. Adding to the complexity is the need to increase the number of women leaders. According to a study by Kele and Pietersen (2015, p. 14), 'higher education institutions in South Africa are still unconsciously gender biased, regardless of how much women having proven themselves'. More recently, Moodly and Toni (2017) highlighted that there seems to be a lack of accountability on the part of universities to implement the national imperatives of appointing women in higher education leadership positions.

Higher education institutions have to make decisions of effective succession planning to ensure that there is a pipeline for the next generation of leaders. Associated with this decision is the need to decide whether to recruit externally or harness and develop the skills of potential internal candidates (Cappelli, 2008). There are pros and cons to both options, but according to Bidwell (2011), focusing on internal candidates may ensure a better fit for the organisation. Thus, if this option is chosen, then the institution through its human resource department should explore what skills need to be developed and how internal programmes can be used to develop the identified skills. This is supported by WiniarskaJanuszewicz and Winiarski (2014), who stated that growing your own timber contributed to building the pipeline and creating skills within the organisation.

For effectiveness, leaders need to possess competencies, some of which are general, but some of which may be specific to the needs of the institutions at a particular time. Some of the more general competencies for effective leadership include: honesty, openness, consulting others, listening skills, negotiation skills, the ability to think both broadly and strategically and the capacity to engage with others (Bartman, 2005). The more specific competencies leaders need to possess, according to Spendlove (2007), are credibility (reputation/ respect), experience and people skills. 'However, universities, particularly in developing countries, have traditionally appointed academic leaders based on seniority in the academic rank regardless of whether or not the candidates have proven leadership competencies' (Ngowi, 2018, p. i). Leadership and management roles, which are perceived to be more middle level such as Heads of School/Department, have evolved into something more strategic and empowering and are no longer solely administrative and operational in their operations (Bolden, Petrov, \& Gosling, 2008). Jooste, Frantz and Waggie (2018) highlighted that there is a need for mentorship and support for leaders in this category and programmes that address the core role of a leader. This raises questions related to the competencies for leaders in the academic sector and questions whether they are fundamentally different from traditional leadership competencies. As we aim to understand the competencies needed to be an effective academic leader, the importance of understanding your own leadership style and how it is perceived by others is important if as leaders we aim to influence our followers in a desired manner to achieve the desired goals. Different leadership styles may affect organisational effectiveness or performance. As there is a widespread acceptance that there is a need for effective leadership in higher education to shape institutional reform and transformation, we have noticed an increase in the rethinking of leadership practices in higher education (Herbst \& Conradie, 2011).

As we look at the need to understand our leadership style and how we impact others through our style and the competencies we should have, there is a need for leadership development programmes that assist potential academic leaders in understanding their leadership styles and the significant impact it may have on others. Kwok, Hanig, Brown and Shen (2018) also highlighted that leadership role identities can be utilised as an effective concept in leadership development programmes in order to promote the transference of behaviours and skills.

\section{Research design Research approach}

This study used a case study qualitative approach to explore the views of how academic and professional support leaders have shifted their thinking of and approach to leadership following their participation in a leadership development programme.

\section{Research strategy}

A case study design was used for this study. According to Zainal (2007), case studies may have been described as a controversial approach but they are recognised in the social 
sciences as they can be used to obtain in-depth explanations of social behaviour. According to Creswell (2017), case study research is a qualitative approach, where the researcher(s) explore a case or cases over a period of time; case(s) explored are in-depth, are detailed and data are collected through an array of information sources and researchers report a case description and case-based themes.

\section{Research method}

This study used a retrospective archival research design. Documents submitted as part of the Programme for Academic and Professional Leaders (P4APL) were reviewed to explore the views of how academic and professional support leaders have shifted their thinking of and approach to leadership following their participation in a leadership development programme, as part of the programme participants were expected to submit reflection half way through the programme and at the end of the programme. According to Finnegan (1996), the use of archival analysis refers to a methodology that can be considered observational research, whereby the researcher examines a set of accumulated documents or archives.

\section{Research setting}

Leadership development has been identified as a core focus area at the (institution name redacted for peer review) historically disadvantaged university. This is evidenced by the fact that leadership was identified as one of the focus areas in the participating university's institutional operating plan. As part of this goal, the university designed a P4APL, which included a combination of (1) theory to foster and understand leadership roles, mentoring, coaching; (2) and a learning project offering practical applications.

\section{Entrée and establishing researcher roles}

The (institution name redacted for peer review) designed P4APLprovided the researchers with an opportunity to conduct a qualitative enquiry through using the case study approach. The researchers were all known by the participants as they were influential in the design and implementation of the programme. All of those who agreed to participate in the programme also agreed to write reflection pieces which were used to conduct this study.

\section{Research participants and sampling methods}

The study sample consisted of 19 conveniently selected academics and professional support staff who participated in a P4APL. All of the participants were expected to write a reflective report as part of the programme and thus all agreed to be part of the study.

\section{Data collection methods}

The P4APL programme was a 12-month programme, and thus midway through the programme and at the end of the programme, the participants had to write reflections.
Reflections were unstructured and guided by the following statement: 'Since you started the programme, what has shifted for you as a leader? Any change in your leadership approach? Any key learnings from the modules you have attended?' Each reflection was submitted electronically and coded by the authors to anonymise the information. The programme is a learning experience for both academics and professional staff and aimed at enhancing participants' understanding of the higher education environment and assist in building personal and professional skills. Participants attended an array of workshops over the 12-month period to develop their leadership skills. The duration of the workshops was between 1 and 2 days; this was dependant on the topic. Included in the programme is the induction, 360 multi-rater assessments, presentations, workshops, networking opportunities, coaching and mentoring sessions, a project related to the university's Institutional Operation Plan (IOP) and four coaching circles.

\section{Strategies employed to ensure data quality and integrity}

To ensure the quality and integrity of the data, an audit trail and chain of evidence was utilised. The records of all the raw data (reflection pieces) were kept securely by the researchers. All records were stored on the laptops/desktops of the researcher, which were password-protected and only known and accessible by the researchers. All the information and the choices made were cross-referenced and discussed amongst the authors before final decisions were made (Nowell, Norris, White, \& Moules, 2017).

\section{Data analysis}

The reflective reports provided by the participants formed the final data set to be analysed. Analysis commenced at the end of the 12-month programme. It was an inductive and emergent process. Content analysis was used to analyse the data obtained from participants. Content analysis is a technique for making presumptions by systematically and objectively identifying special characteristics in data (Grove, Burns, \& Gray, 2014). This technique was suitable for the study because of its interpretive approach and nature, which gave the end result of understanding the perceptions of the participants regarding their leadership style. The analysis was conducted by two independent researchers who coded the information and presented the emerging themes. The collated codes and themes were presented by the researchers to the research team who further cross-checked and discussed differences until consensus was reached. There were no real changes to be made; only clarifications needed.

\section{Reporting style}

The study reports the findings according to themes. Each key finding is supported by at least three direct participant quotations. 


\section{Ethical consideration}

The research participants were informed that their participation in the study was voluntary. The reflections were submitted electronically and coded by the researchers so that the participants could remain anonymous. The limitations in relation to anonymity were discussed with the participants based on their role within the university. All participants agreed to continue to participate in light of these limitations. Ethical approval to conduct this study was obtained. HS19/6/1 and 14/9/23.

\section{Results}

Participants in this study consisted of 11 females and 8 males, who were predominantly academic leaders $(n=15)$ and academic professional support leaders $(n=4)$. Based on the data provided, four key themes emerged, namely, (1) ethical leadership; (2) leadership as building others; (3) sense of ownership; and (4) the complexity of leading, are presented and discussed in the following section.

\section{Ethical leadership}

Participants highlighted their appreciation for ethical leadership, as displayed by other individuals in management positions within their institutions. They highlighted that ethical leadership was characterised by consistency, fairness and good-natured action geared towards building others rather than ruling. Additionally, participants highlighted that they perceived those who demonstrated ethical leadership to have a strong moral and ethical character. These ideas expressed by participants are presented in the excerpts below:

'Finally, I have learnt that leadership should be ethical. I am encouraged by many of the university top management who made presentations (who shared of their personal leadership styles) are highly ethical persons. A sound value system needs no words for understanding. Saint Francis' words comes to mind, do good, only use words when it is necessary.' (P2)

'The coaching conversations also spoke to the need for ethical leadership that builds rather than rules, that is fair and consistent and sets the standard by doing rather than saying.' (P18)

'Ethical leadership has become evident in how we must approach situations. Although ethics is a word commonly used, applying it in your leadership can be challenging but is important.' (P4)

\section{Leadership as building and empowering others}

Some of the participants highlighted (11/19) that they have come to appreciate the concept of distributed leadership through their participation in the programme. For participants, distributed leadership included the sharing of skills and knowledge with others for the development of future leaders. Participants suggested that for distributed leadership to be achieved, they need to act as agents of the empowerment and encouragement of others through the process of social interaction. This developed understanding of the concept of distributed leadership, as reported by participants, is depicted in the excerpts below:
'Empowering team and build future leaders - "every person is an agent of change." I have made a concerted effort not to take charge at all times and I have been requesting volunteers to co-ordinate projects in the faculty so as to expose them to leadership skills and competencies.' (P3)

'... via the P4APL programme I have come to realize the importance of having a "one-anothering" relationships with my fellow academics, wherein I serve as an encourager, builder and teacher. Hence, I now see that transience of my impact and the lasting influence on academics and support staff, who now work together in collegial ways to develop, rejuvenate and create a supportive conducive environment.' (P5)

'I now make every effort to develop a leadership style that can cross boundaries, where I develop the cultural intelligence to be able to work together with people from different backgrounds. My ideal, currently, is to develop a democratic leadership which, in my opinion, affords participation and freedom to other group members. It would also encourage active decision-making and discussion which would have an all-round positive effect.' (P7)

\section{Sense of ownership}

More than half of the participants reported on the concept of a sense of ownership, as they are not passive agents who are limited by the directions and orders provided by others (10/19). Rather, participants experienced a shift in view and greater understanding throughout the programme as they now regard themselves as active agents able to take initiative and engage and positively contribute towards decision-making processes. Therefore, participants claimed a sense of ownership and accountability to bring about transformation and contributing towards the success of their programmes, students and, in turn, their institutions. The shift in participants' views of leadership to incorporate a sense of ownership is displayed in the excerpts below:

'My inside shifted from looking at senior management to bring about change to a place of taking ownership of the change myself. With this being said, I realised that I have to discern what my area of leadership is where I can bring about this change.' (P4)

'We, on the ground, have to take ownership of our programmes, our students and our institution to ensure its success in going forward.' (P15)

'I had the opportunity to reflect on motivating my team to take ownership and take authority with responsibility seriously.' (P6)

\section{Complexity of leadership styles}

As participants reflected upon their leadership styles throughout the programme, they became increasingly cognisant of the need to adapt. According to participants, adaption through the process of self-reflection was required as leadership is not instructional or rigid, but rather flexible and adaptive so that it may be applied effectively to varying contexts and situations. Many of the participants (14/19) throughout the conversation alluded to the fact that there is no 'right' leadership style and that leadership styles are shaped by contextual factors such as experiences and contexts and may be further adapted so that it may be 
effective within a particular environment. These views expressed by participants are contained in the excerpts presented below:

"At this point, I believe that there is no one "right" leadership style but that which lays the foundation for growth and stability within an organization.' (P8)

'I had been describing myself as a democratic leader, but the self-assessment exercise on leadership portrayed me as an autocratic leader. This made me to understand that being an autocratic leader does not always have a negative connotation. I began to realize that one's experiences and surrounding circumstances are some of the factors that contribute in shaping one's leadership style.' (P11)

'P4APL has brought me to the conclusion that there is no one or perfect leadership style and that being a leader means reflecting on your own actions and behaviour and being able to adapt to situations and people as your style in one environment will not be as effective in another.' (P14)

\section{Discussion}

The purpose of this article is to explore the views of how academic and professional support leaders have shifted their thinking of and approach to leadership following their participation in a leadership development programme. From the results, it is evident that the programme had an impact on how participants started reflecting on leadership styles broader than the usual description of leadership styles. Participating in the leadership programme facilitated reflection on aspects such as ethical leadership, the importance of a leader in building capacity in others and taking ownership as well as the complexity of different leadership styles.

When unpacking the aspect of ethical leadership, the participants highlighted the importance of (role) modelling. It was through the actions rather than the words of the facilitators (leaders in higher education) that values such as integrity contributed to the identification of ethical leadership. Institutional integrity amongst leaders in higher education arose as an important consideration amongst participants during the focus group discussions. Jean-Louis (2017) highlighted that leaders in the higher education sector have the responsibility to manage and lead change in a strategic, sustainable and ethical manner. Thus, the role of a leader is more than just their personality; it includes the values and content of leadership and thus how the leader portrays what s/he stands for (Pityana, 2017).

In addition, the notion of distributed leadership was raised. Distributed leadership contributes to the development of future leaders, through sharing (Chin, 2015). This involvement of others highlights the social dimension of leadership, which facilitates engagement in teams and groups. The findings of the study highlighted that leadership has a social dimension, which highlights the shared nature of the work. According to $\mathrm{Ba}$ (2015), successful leaders encourage their followers to do more than they think they are capable of doing. The participants expressed that they realised that leadership had a social dimension and this encouraged them to engage and empower others.

The study also touched on the aspect of ownership, where the participants expressed that as active agents it becomes important to take initiative and contribute positively towards the decision-making process. This involves taking ownership and recognising that the success of the institution rests on the shoulders of all and not only those in senior management positions. The aspect of ethical leadership referred to earlier has been found to directly affect ownership, which encourages responsibility towards your job (Avey, Wernsing, \& Palanski, 2012) and having an interest in the success of the institution. The realisation amongst participants that leadership is in the hands of not only the senior management but all academic and support staff can demonstrate exceptional leadership qualities. A sense of ownership can be seen as an aspect of sustainability, and it can be argued that this sense of ownership will ensure that the person is likely to contribute to the success of the institution.

As we investigate the word 'ownership', the difference between accountability and ownership is raised. Literature indicates that the business definition of the difference is the feeling of responsibility of your task at the company and a generalised sense of ownership regarding the company's success as a whole. In the higher education sector, institutions are facing pressure to improve governance to facilitate both internal and external accountability. According to literature, the aspect of accountability in higher education is influenced by public policy, government authority, professional authority and the end users (students, parents and community) (Burke \& Associates, 2005).

The complexity of leadership was also discussed and the realisation that there cannot be a one-size-fits-all approach was accepted. A combined leadership style is often applied where the role of the leader is to lead teams (Chin, 2015) as is the case in higher education. According to Uhl-Bien and Arena (2017), there is a need for adaptability amongst leaders in organisations. The authors highlight that in their complexity leadership model, leaders need to enable adaptive spaces in ways that are nurturing and protective. The idea of being adaptive and creating adaptive spaces is reflected in the comments of participants, where they highlight their thoughts on their own leadership style, but how they need to adapt. Important for developers of leadership development programmes is that they should recognise the inherent identity and strength of the individual and not advocate that a leader has to reconstruct their own leadership identity. Adaptability becomes an important aspect as there is often a need for leaders to apply a different or a combination of leadership styles depending on the context (Chin, 2015).

\section{Limitations and recommendations}

Although this study was limited to a confined sample of participants and thus cannot be generalised, the concept of using leadership development programmes to create an 
awareness of the changes happening in leadership in the higher education sector presents us with the opportunities to address the complexity of formal and informal leadership in higher education.

\section{Conclusion}

The current study aimed to explore the views of academic and professional support leaders on what has shifted in their thinking of and approach to leadership following their participation in a leadership development programme. It is evident from the results that participants had made personal adjustments in the way they viewed leadership with a greater sense of ownership and understanding of distributed leadership.

\section{Acknowledgements Competing interests}

The authors have declared that no competing interests exist.

\section{Authors' contributions}

J.F. drafted the article based on the data and A.R. and V.L. contributed to refining the article prior to submission.

\section{Funding information}

This research received no specific grant from any funding agency in the public, commercial or non-profit sector.

\section{Data availability statement}

Data generated will be stored and can be made available on request.

\section{Disclaimer}

The views and opinions expressed in this article are those of the authors and do not necessarily reflect the official policy or position of any affiliated agency of the authors.

\section{References}

Avey, J.B., Wernsing, T.S., \& Palanski, M.E. (2012). Exploring the process of ethical leadership: The mediating role of employee voice and psychological ownership. Journal of Business Ethics, 107(1), 21-34. https://doi.org/10.1007/s10551-012Journal

Ba, B.G.M. (2015). Understanding leadership and empowerment in the workplace. European Scientific Journal, 11(35), 342-365.

Bartman, D. (2005). The great eight competencies: A criterion-centric approach to validation. Journal of Applied Psychology, 90(6), 1185-1203. https://doi. org/10.1037/0021-9010.90.6.1185
Bidwell, M. (2011). Paying more to get less: The effects of external hiring versus internal mobility. Administrative Science Quarterly, 56(3), 369-407. https://doi. org/10.1177/0001839211433562

Bolden, R., Petrov, G., \& Gosling, J. (2008). Developing collective leadership in higher education. Leadership Foundation for Higher Education.

Burke, J.C., \& Associates (2005). Achieving accountability in higher education Balancing public, academic and market demands. San Francisco, CA: Jossey-Bass.

Cappelli, P. (2008). Talent management for the twenty-first century. Harvard Business Review, 86(3), 74.

Chin, R.J. (2015). Examining teamwork and leadership in the fields of public administration, leadership, and management. Team Performance Management: An International Journal, 21(3/4), 199-216. https://doi.org/10.1108/TPM-07An Internation

Creswell, J.W. (2007). Qualitative inquiry and research design: Choosing among five approaches. Lincoln, OR: Sage Publications.

Finnegan, R. (1996). Using documents. In R. Sapsford \& V. Jupp (Eds.), Data collection and analysis (pp. 138-151). London: Sage.

Grove, S.K., Burns, N., \& Gray, J. (2014). Understanding nursing research: Building an evidence-based practice. Elsevier Health Sciences.

Herbst, T.H., \& Conradie, P.D. (2011). Leadership effectiveness in higher education: Managerial self-perceptions versus perceptions of others. SA Journal of Industrial Psychology, 37(1), 1-14. https://doi.org/10.4102/sajip.v37i1.867

Jean-Louis, M. (2017). Change leadership, ethics and the future of higher education. In D. Singh \& C. Stückelberger (Eds.), Ethics in higher education values-driven leaders for the future (pp. 123-132). Geneva: Globethics.net.

Jones, S., Harvey, M., Lefoe, G., \& Ryland, K. (2014). Synthesising theory and practice: Distributed leadership in higher education. Educational Management Administration \& Leadership, 42(5), 603-619. https://doi.org/10.1177/1741 143213510506

Jooste, K., Frantz, J., \& Waggie, F. (2018). Challenges of academic healthcare leaders in a higher education context in South Africa. Educational Management Administration \& Leadership, 46(4), 692-708. https://doi.org/10.1177/17411 43216688468

Kele, T., \& Pietersen, J. (2015). Women leaders in a South African higher education institution: Narrations of their leadership operations. International Journal of Sustainable Development, 8(5), 11-15.

Kulati, T. (2001). Leadership, management, and institutional change in South African higher education: 1994-1999. Retrieved from http://www.epu.uwc.ac.za/ ConferenceProceedings/Papers/Kulati.doc

Kwok, N., Hanig, S., Brown, D.J., \& Shen, W. (2018). How leader role identity influences the process of leader emergence: A social network analysis. Leadership Quarterly, 29(6), 648-662. https://doi.org/10.1016/j.leaqua.2018.04.003

Moodly, A., \& Toni, N.M. (2017). Accessing higher education leadership: Towards a framework for women's professional development. South African Journal of Higher Education, 31(3), 138-153. https://doi.org/10.20853/31-3-917

Ngowi, A. (2018). Recruiting and developing academic leaders. In M.E. Auer \& K.S. Kim (Eds.), Engineering education for a smart society (pp. 82-91). Switzerland: Springer International Publishing. https://doi.org/10.1007/978-3-319-60937-9_7

Nowell, L.S., Norris, J.M., White, D.E., \& Moules, N.J. (2017). Thematic analysis: Striving to meet the trustworthiness criteria. International Journal of Qualitative Methods, 16, 1-13. https://doi.org/10.1177/1609406917733847

Parrish, D.R. (2015). The relevance of emotional intelligence for leadership in a higher education context. Studies in Higher Education, 40(5), 812-837. https://doi.org/ 10.1080/03075079.2013.842225

Pityana, N. (2017). Leadership and ethics in higher education: Some perspectives from experience. In D. Singh \& C. Stückelberger (Eds.), Ethics in higher education values-driven leaders for the future (pp. 133-161). Geneva: Globethics.net.

Seale, O.J.J. (2015). Building leadership and management capacity for deans in South Africa higher education (Doctoral dissertation). South Africa: WITS Institutional Repository

Spendlove, M. (2007). Competencies for effective leadership in higher education. International Journal of Education Management, 21(5), 407-417. https://doi. org/10.1108/09513540710760183

Uhl-Bien, M., \& Arena, M. (2017). Complexity leadership: Enabling people and organizations for adaptability. Organizational Dynamics, 46(1), 9-20. https://doi. org/10.1016/j.orgdyn.2016.12.001

Winiarska-Januszewicz, A., \& Winiarski, J. (2014). Advancing leadership pipeline through the development of high-potential employees. Journal of Intercultural Management, 6(1), 17-25. https://doi.org/10.2478/joim-2014-0002

Zainal, Z. (2007). Case study as a research method. Kemanusiaan, 9, 1-6. 